\title{
Study of psychological features of anxiety in adolescents and youth in school and university
}

\author{
Victoria Kolyagina $^{1,{ }^{*}}$, Konstantin Yadrov $^{1}$, Slavitsa Golubovich $^{2}$, Anastasia $_{\text {Chebryakova }}{ }^{1}$, \\ Serafima Mityanets ${ }^{1}$ \\ ${ }^{1}$ Moscow Region State University, 24, Vera Voloshina str., 141014, Mytishchi, Russia \\ ${ }^{2}$ University of Belgrade, 2, Visokog Stevana str., 11000, Belgrade, Serbia
}

\begin{abstract}
The actual topic of modern psychology is the psychological health of students and youth. In further socialization and adaptation in society, a major role is played by the absence of anxiety in the psychological characteristics of children. It is very important that the future generation enters adulthood without a neurotic history. Therefore, the study of the characteristics of the manifestation of anxiety at school and university, its types and specific manifestations is one of the main aspects of the study of modern psychological science. The purpose of the paper is to consider the characteristics of the manifestation of anxiety in students of the fifth, ninth grades and students of the last courses of university. Materials and methods. The paper analyzes the types of anxiety of schoolchildren and students, the features of its manifestation in various age and gender groups. The study was conducted using psychological tests to identify the dependence of the level of anxiety on gender, age and the influence of the external environment. The research data were processed using mathematical statistics. The results of the study. A study of the manifestation of anxiety features showed that the school anxiety decreases and interpersonal anxiety increases with age. The data indicate the specificity in the gender characteristics of the manifestation of anxiety. High indicators of anxiety show the need to create special conditions for the upbringing and education of children in educational institutions to prevent it and reduce the level of neuroticism in schoolchildren and students. Discussion and conclusions. The results of the study can be useful to teachers, psychologists, and teachers for understanding the psychological component of the development of schoolchildren and students, for their further successful psychological maturation.
\end{abstract}

\section{Introduction}

Trends in increasing anxiety among schoolchildren and students have attracted the attention of many scientists in different fields: physicians, psychologists, educators, and sociologists. The relentless growth of this emotional disturbance among adolescents and youth raises the question of its more detailed study, prevention and correction. Psychologist A.M. Prikhozhan noted that "the problem of anxiety occupies a special place in modern

\footnotetext{
* Corresponding author: hlizova_iv@mail.ru
} 
scientific knowledge. This psychological phenomenon is assessed "as the central problem of modern civilization". [7] On the one hand, an increase in intellectual workload, and on the other hand, constant stressful situations associated with learning lead to an increase in emotional distress among children, which affects their psychological health, their further development, preventing full adaptation and socialization in society. School and university anxiety involve various aspects of distress. It can be expressed in different levels and manifestations: excitement, anxiety in the educational process, in the refusal of educational activities, and much more [5,8].

Many studies emphasize the social nature of anxiety. Scientist N.V. Imedadze believes that anxiety is a specific socialized emotion. Studying anxiety in a child population, V.R. Kislovskaya notes that there is a reliable correlation between the manifestation of anxiety and sociometric status in all age periods of development. Thesis by V.M. Minaeva reveals anxiety as a function of social communication. [6]

Foreign authors consider anxiety as a personal characteristic of a person. H. Heckhausen considers anxiety a personality trait, and Ch.D. Spielberg defines it as a personality feature that is prone to anxiety in various threatening situations [1].

Many domestic scientists devoted to the study of the manifestations of anxiety among students: V.I. Garbuzov, A.I. Zakharov, R.A. Zachepitsky, A.S. Spivakovskaya and others. They pointed out that one of the root causes of school neurotic conditions is the manifestation of anxiety [3]. An increased level of anxiety creates difficulties in the perception of educational material, reduces the intellectual potential and the level of mental performance, which affects the overall performance at school or university [2].

Anxiety can manifest itself in the most significant areas of communication or other types of activity, as well as be a consequence of intrapersonal conflicts, problems with the adoption of one's appearance and oneself [4]. Often schoolchildren and students may experience pronounced neurotic, neurosis-like and psychosomatic problems, in the nature of which are self-doubt, dissatisfaction with social status, communication difficulties, low self-esteem, etc. All these negative manifestations interfere not only with successful learning, but also with further development of the personality. Therefore, it is important not only to diagnose, but also to carry out prevention and correction of emotional difficulties in students [9].

The problem of negative psychological states in learning is of great practical importance. If teachers, professors, parents have knowledge about the emotional problems of students, they will be able to more harmoniously build the educational process.

\section{Research methods}

The study was conducted on the basis of educational institutions: schools and universities of the Moscow region. The study involved 300 students (fifth, ninth grades of a school and final year students of Moscow Region State University). To determine the level of anxiety of schoolchildren and students, as well as its dependence on gender, age and characteristics of external factors, the "Anxiety Scale" by R. Kondash was used. This technique is a series of test questions that contain a description of situations related to study, communication with teachers; situations actualizing self-image; communication situations. The peculiarity of the methodology is that the respondent does not evaluate the presence of any manifestations of anxiety in himself, but how specific circumstances can cause anxiety. The assessment is made using a 4-point scale, where 0 is the absence of anxiety in this situation, and 4 is severe anxiety, fear. This technique allows assessing the level of general, school, interpersonal and self-esteem anxiety of each student and age-sex group as a whole; track its change depending on various factors, using average statistics in a specific group. To process the obtained data, the method of statistical mathematical analysis was used. The 
data was subjected to computer mathematical and statistical processing using the Microsoft Office Excel (Excel) and IBM SPSS Statistics version 24.

\section{Research results}

The data obtained during the study made it possible to identify the most problematic (causing the most intense anxiety) questions for each age and gender, to determine the type of anxiety that dominates in each age-sex group.

In the experiment, R. Kondash's questionnaire was used to identify the peculiarities of anxiety in adolescents of the fifth and ninth grades in school and young people studying in the last year of undergraduate university. The results obtained during the psychological examination can be interpreted in terms of quantitative and qualitative indicators.

Quantitative analysis allowed us to determine the distribution of types of anxiety among the respondents.

Features of the manifestation of anxiety types in fifth graders who took part in the study are clearly presented in diagram No. 1

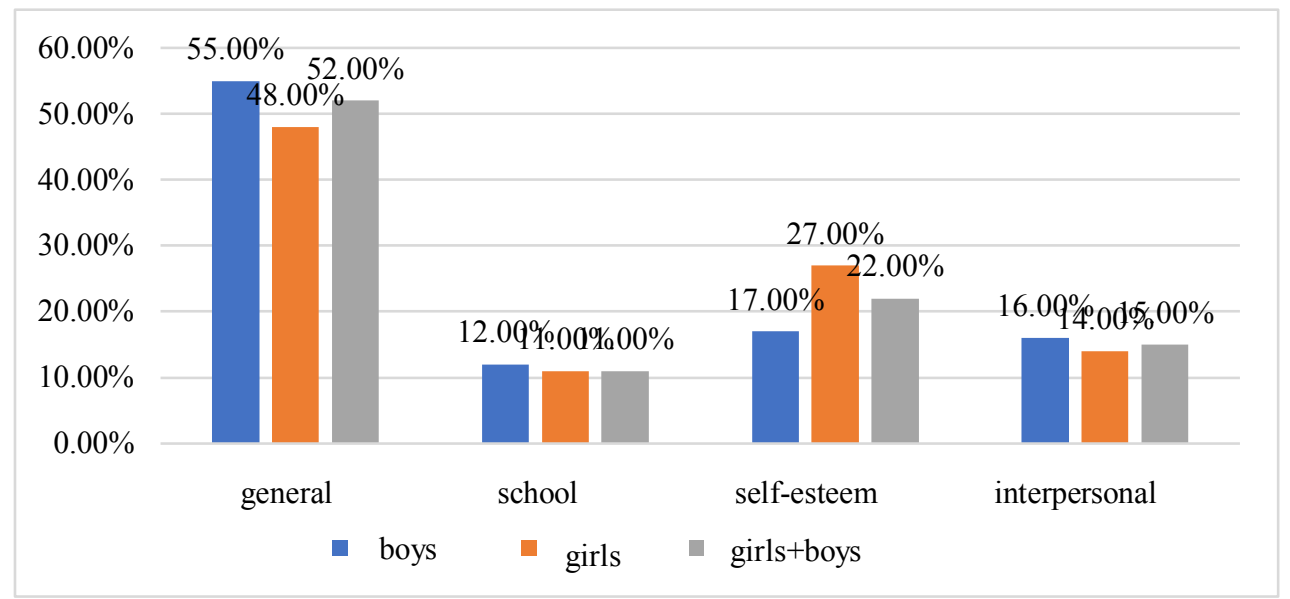

Fig. 1. The ratio of different types of anxiety in students of the fifth grade of school.

In the group of fifth graders $(52 \%)$, the respondents showed the presence of general anxiety, which says that more than half of the respondents experience anxiety. School anxiety is detected in $11 \%$ of respondents, which means that at this age, school and everything connected with it does not cause worries turning into anxiety for many children. It is interesting to note that there are no gender differences in the manifestation of anxiety among the examined respondents of this age, i.e. anxiety is observed in children regardless of gender. Interpersonal and self-esteem anxiety is present in a small percentage of the children studied (15\%). The anxiety manifested in fifth graders at this stage of development is not related to the school situation and the personal characteristics of children, it has other reasons, good enough for general anxiety manifestation.

Peculiarities of the manifestation of anxiety types in ninth-graders who took part in the study are clearly presented in diagram No. 2 


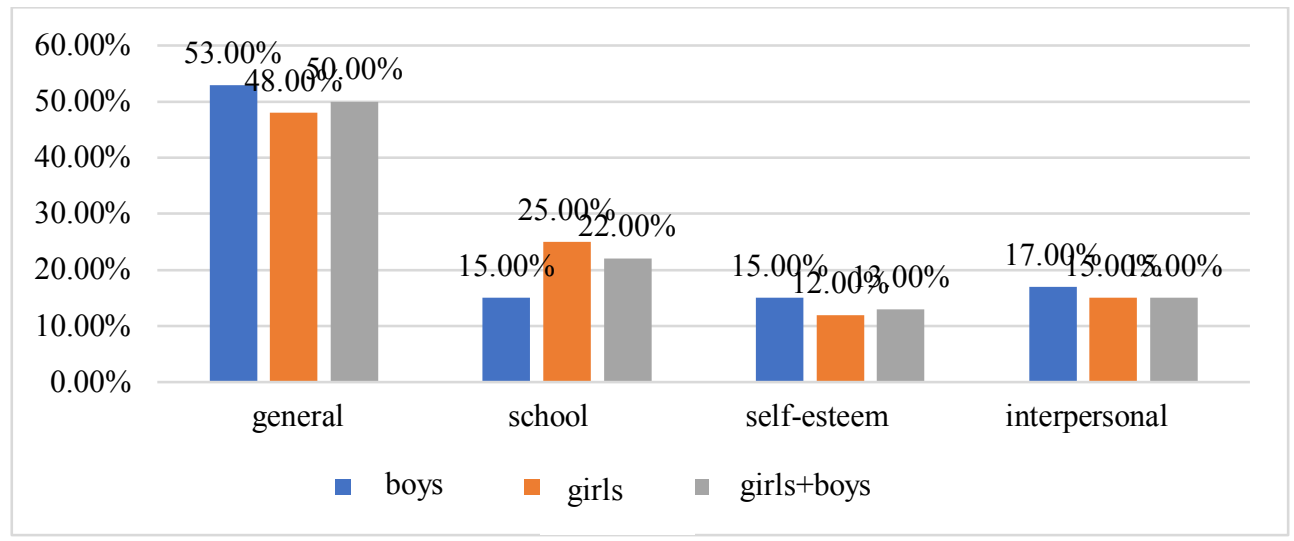

Fig. 2. The ratio of different types of anxiety in students of the ninth grade of school.

The general anxiety among students in 9th grade was identified in $50 \%$ of the surveyed high school students. Several years of schooling did not lead to a decrease in general anxiety, it remains relatively unchanged. In this age category, school anxiety rates increase $(22 \%)$ compared with the fifth grade. This particular category showed gender peculiarities girls are a little more concerned about school problems which cause anxiety than boys. Indicators of interpersonal anxiety remain approximately in the same proportions. It is interesting to note that self-esteem anxiety decreases in the female part $(12 \%)$ compared with the fifth grade (27\%). We can assume that there are situations in which the self-esteem of the female part is significantly improved, which leads to a decrease in the rates of this type of anxiety with time.

Features of the manifestation of anxiety types in students of the last year of study at the university are clearly presented in diagram No. 3 .

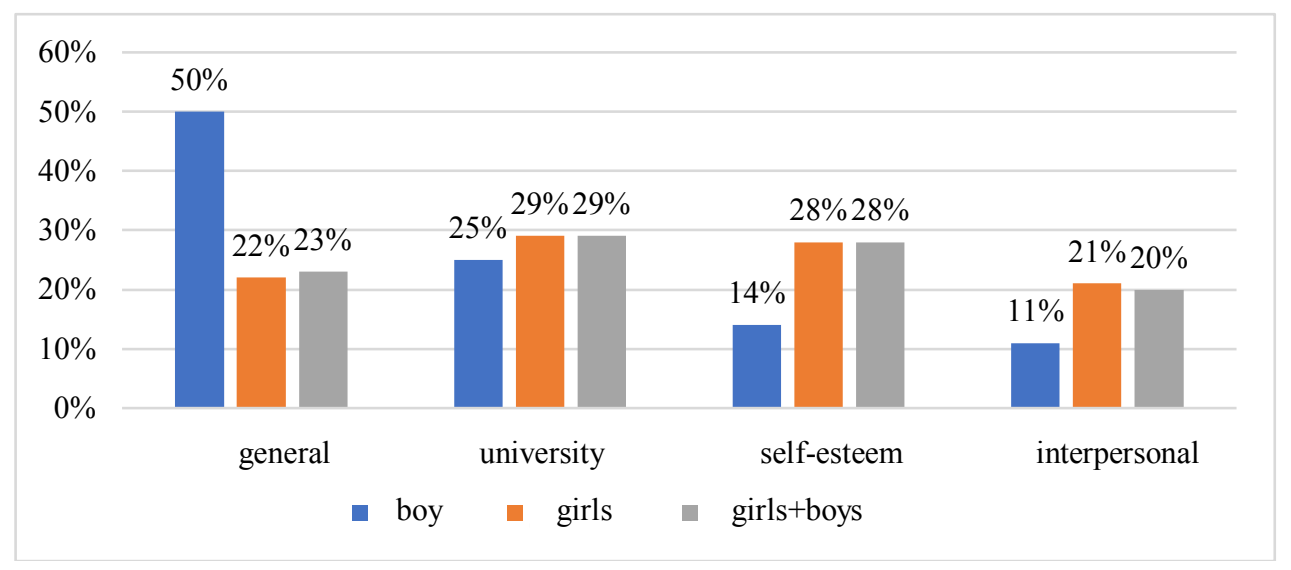

Fig. 3. The ratio of different types of anxiety among students of the last year of university.

The indicators of general anxiety among students in the last year of university are already significantly lower $(23 \%)$, with age, the level of general anxiety decreases. The manifested high rates of general anxiety in the male part being studied may indicate individual psychological characteristics of the students being examined. We can assume that the last year of the university is a significant stage for students, especially young men, for whom more serious changes in life (army, job search, etc.) occur, unlike girls who have other life values and goals, which manifested in different indicators. School anxiety is already becoming university anxiety, and students are worried about exams, grades, relationships 
with teachers. Therefore, indicators of this type of anxiety are distinguished by higher numbers compared to school ones $(29 \%)$. There is also an increase in indicators of selfesteem and interpersonal anxiety compared to school ones. The last university course can be more stressful for students, because it is associated with examination certification, a change in life habits and ways of life, changing goals and summing up results, all this can manifest itself in anxiety about the future and increased demands on oneself, one's knowledge, personal characteristics, which is manifested in anxiety fears.

Quantitative analysis made it possible to compile a list of dominant stimuli and situations in which anxiety is manifested in the students under consideration. The data obtained made it possible to compile a list of the main anxiety groups of adolescents and youth. The analysis of experimental data was carried out using Factor analysis. The result of the analysis was the allocation of 11 factors that form approximately $64 \%$ of the variance. Table No. 1 presents the identified factors and situations causing anxiety.

Table 1. Comparison of the factor and stimuli for anxiety.

\begin{tabular}{|c|c|}
\hline $\begin{array}{l}\text { Factor } \\
\text { No. }\end{array}$ & Stimuli defining anxiety \\
\hline Factor 1 & $\begin{array}{l}\text { Stimuli that alarms respondents from the danger posed by negative adults (parents } \\
\text { after the parent meeting, strangers who carry the danger) }\end{array}$ \\
\hline Factor 2 & $\begin{array}{l}\text { Stimuli disturbing respondents associated with experiences of their social } \\
\text { attractiveness }\end{array}$ \\
\hline Factor 3 & $\begin{array}{l}\text { Stimuli disturbing respondents related to social communication and fear of its } \\
\text { negative consequences }\end{array}$ \\
\hline Factor 4 & $\begin{array}{l}\text { Stimuli disturbing respondents related to public speaking, reaction and evaluation of } \\
\text { external observers }\end{array}$ \\
\hline Factor 5 & Stimuli disturbing respondents related to school or university success \\
\hline Factor 6 & $\begin{array}{l}\text { Stimuli disturbing respondents related to the assessment of school or university } \\
\text { knowledge }\end{array}$ \\
\hline Factor 7 & $\begin{array}{l}\text { Stimuli disturbing respondents associated with undesirable social situations } \\
\text { associated with a public demonstration of appearance and intellectual abilities }\end{array}$ \\
\hline Factor 8 & $\begin{array}{l}\text { Stimuli disturbing respondents related to communication with adults who has } \\
\text { managerial status (director, teacher) }\end{array}$ \\
\hline Factor 9 & $\begin{array}{l}\text { Stimuli disturbing respondents in situations where everyone do not see the } \\
\text { personality and adult in them }\end{array}$ \\
\hline $\begin{array}{l}\text { Factor } \\
10\end{array}$ & $\begin{array}{l}\text { Stimuli disturbing respondents in situations of non-acceptance of their personal and } \\
\text { external characteristics }\end{array}$ \\
\hline $\begin{array}{l}\text { Factor } \\
11\end{array}$ & Gender-related stimuli and negative future implications \\
\hline
\end{tabular}

The data obtained by factor analysis show that there is a correlation of anxiety with social and within personal indicators in the identified indicators. Students experiencing negative consequences after communicating with significant adults (factor 1). Fears of their external unattractiveness and problems in communicating with peers, which is characteristic of adolescence (factor 2). Fear that communication may lead to undesirable or negative consequences (factor 3). Speaking in public, the fear of being socially unattractive and causing laughter or aggression against you cause increased anxiety (factor 4). School or university anxiety is associated with the problems of obtaining an assessment, a survey by a teacher, success in knowledge and more (factor 5). Answers at the blackboard, exams, session, getting a bad mark cause strong anxiety experience (factor 6). Situations in which 
attention is drawn to the appearance and an assessment of personal characteristics is made (factor 7). Communication with the school principal or the dean of the faculty, as well as the teacher or professor, is associated with stress (factor 8). Protest forms of behavior and anxiety arise in young people in response to resentment, impaired pride, dissatisfaction with demands or relationships with loved ones who continue to communicate in a constant style continuing from childhood (factor 9). Adolescence and youth are often associated with a rejection of their external or personal qualities, inferiority complexes, low self-esteem, which causes worries and anxiety (factor 10). Factor 11 revealed the interconnection of gender characteristics and feelings about the negative consequences of the future, which indicates the existing gender differences in the manifestation of anxiety, which requires a deeper understanding and detailed study. All identified factors confirm the already existing data on the psychological reactions within these age limits related to the social environment, communication, and internal personality problems of young people.

In the process of a qualitative analysis of the results of psychodiagnostic studies, significant differences were found in the characteristics of nonparametric indicators.

The use of the nonparametric Mann-Whitney difference criterion helped mathematically determine the significant differences in anxiety rates among students in the fifth and ninth grades of the school. Table No. 2 presents the characteristics of the identified ranks of indicators of fifth graders in comparison with ninth graders.

Table 2. Comparative indicators of fifth and ninth graders.

\begin{tabular}{|c|c|c|c|c|}
\hline & Age & $\mathbf{N}$ & Middle rank & Sum of ranks \\
\hline \multirow{3}{*}{ General anxiety } & $5^{\text {th }}$ grade & 100 & 103.67 & 10367.00 \\
\hline & $9^{\text {th }}$ grade & 100 & 97.33 & 9733.00 \\
\hline & Total & 200 & & \\
\hline \multirow{3}{*}{ School anxiety } & $5^{\text {th }}$ grade & 100 & 99.59 & 9958.50 \\
\hline & $9^{\text {th }}$ grade & 100 & 101.42 & 10141.50 \\
\hline & Total & 200 & & \\
\hline \multirow{3}{*}{$\begin{array}{l}\text { Self-esteem } \\
\text { anxiety }\end{array}$} & $5^{\text {th }}$ grade & 100 & 108.06 & 10806.00 \\
\hline & $9^{\text {th }}$ grade & 100 & 92.94 & 9294.00 \\
\hline & Total & 200 & & \\
\hline \multirow{3}{*}{$\begin{array}{l}\text { Interpersonal } \\
\text { anxiety }\end{array}$} & $5^{\text {th }}$ grade & 100 & 110.67 & 11067.00 \\
\hline & $9^{\text {th }}$ grade & 100 & 90.33 & 9033.00 \\
\hline & Total & 200 & & \\
\hline
\end{tabular}

Table 3 presents the statistical criteria of Mann-Whitney to compare the types of anxiety of students in the fifth and ninth grades.

Table 3. Mann-Whitney statistical tests.

\begin{tabular}{|c|c|c|c|c|}
\hline & $\begin{array}{c}\text { General } \\
\text { anxiety }\end{array}$ & $\begin{array}{c}\text { School } \\
\text { anxiety }\end{array}$ & $\begin{array}{c}\text { Self-esteem } \\
\text { anxiety }\end{array}$ & $\begin{array}{c}\text { Interpersonal } \\
\text { anxiety }\end{array}$ \\
\hline Mann-Whitney U test & 4683.000 & 4908.500 & 4244.000 & 3983.000 \\
\hline $\begin{array}{c}\text { Wilcoxon test statistic } \\
\text { W }\end{array}$ & 9733.000 & 9958.500 & 9294.000 & 9033.000 \\
\hline Z & -.833 & -.272 & -2.125 & -2.920 \\
\hline $\begin{array}{c}\text { Asymptotic value } \\
\text { (two-way) }\end{array}$ & 0.405 & 0.785 & 0.034 & 0.003 \\
\hline
\end{tabular}

The data obtained by a comparative analysis of indicators of students in fifth and ninth grades indicate that the significance level on the scale of self-esteem and interpersonal anxiety is $\mathrm{p}<0.05$, which confirms the data that self-esteem and interpersonal anxiety decrease over time. As can be seen in the diagram number 1 and number 2. Perhaps, 
schooling as a social factor of adaptation and socialization plays the role in this. For general and school anxiety, a statistically significant difference is not confirmed, $\mathrm{p}>0.05$. According to the test, a nonparametric criterion for the uniformity of the samples concluded that there was no statistically significant difference between the general and school anxiety scales.

The use of the nonparametric Mann-Whitney difference criterion helped mathematically determine significant differences in anxiety rates among fifth and final year university students. Table No. 4 presents the characteristics of the identified ranks of indicators of ninth graders in comparison with students.

Table 4. Comparative indicators of ninth graders and students.

\begin{tabular}{|c|c|c|c|c|}
\hline & Age & $\mathbf{N}$ & Middle rank & Sum of ranks \\
\hline \multirow{3}{*}{$\begin{array}{l}\text { General } \\
\text { anxiety }\end{array}$} & Students & 100 & 98.92 & 9891.50 \\
\hline & $9^{\text {th }}$ grade & 100 & 102.09 & 10208.50 \\
\hline & Total & 200 & & \\
\hline \multirow{3}{*}{$\begin{array}{l}\text { School } \\
\text { anxiety }\end{array}$} & \begin{tabular}{|l|} 
Students \\
\end{tabular} & 100 & 105.66 & 10565.50 \\
\hline & $9^{\text {th }}$ grade & 100 & 95.35 & 9534.50 \\
\hline & Total & 200 & & \\
\hline \multirow{3}{*}{$\begin{array}{l}\text { Self-esteem } \\
\text { anxiety }\end{array}$} & \begin{tabular}{|l|} 
Students \\
\end{tabular} & 100 & 97.22 & 9722.00 \\
\hline & $9^{\text {th }}$ grade & 100 & 103.78 & 10378.00 \\
\hline & Total & 200 & & \\
\hline \multirow{3}{*}{$\begin{array}{c}\text { Interpersonal } \\
\text { anxiety }\end{array}$} & Students & 100 & 96.68 & 9668.0 \\
\hline & \begin{tabular}{|l|}
$9^{\text {th }}$ grade \\
\end{tabular} & 100 & 104.32 & 10432.0 \\
\hline & Total & 200 & & \\
\hline
\end{tabular}

Graduates of ninth grade and final year students have similar levels of anxiety. For all indicators, there is no difference in the statistical analysis of Mann-Whitney. This may be caused by the fact that the self-identification of the respondents manifests itself as in graduates of an educational institution who have increased levels of stress associated with a further change in their familiar environment and concern about their life situation. Students in the fifth grade of the school do not have such data.

Table 5 presents the statistical criteria of Mann-Whitney to compare the types of anxiety of students in last year of university and students in the ninth grade of school.

Table 5. Mann-Whitney statistical tests.

\begin{tabular}{|l|r|r|r|r|}
\hline & \multicolumn{1}{|c|}{$\begin{array}{c}\text { General } \\
\text { anxiety }\end{array}$} & \multicolumn{1}{|c|}{ School anxiety } & \multicolumn{1}{c|}{$\begin{array}{c}\text { Self-esteem } \\
\text { anxiety }\end{array}$} & \multicolumn{1}{c|}{$\begin{array}{c}\text { Interpersonal } \\
\text { anxiety }\end{array}$} \\
\hline $\begin{array}{l}\text { Mann-Whitney U } \\
\text { test }\end{array}$ & 4841.500 & 4484.500 & 4672.000 & 4618.000 \\
\hline $\begin{array}{l}\text { Wilcoxon test } \\
\text { statistic W }\end{array}$ & 9891.500 & 9534.500 & 9722.000 & 9668.000 \\
\hline Z & -.436 & -1.449 & -1.042 & -1.290 \\
\hline $\begin{array}{l}\text { Asymptotic value } \\
\text { (two-way) }\end{array}$ & 0.663 & 0.147 & 0.297 & 0.197 \\
\hline
\end{tabular}

A similar analysis of the levels of anxiety on 4 scales between the ninth grade of school and the last year of university did not reveal statistically significant differences in the levels of anxiety.

Table No. 6 shows statistically reliable data of the types of anxiety in adolescents of the fifth, ninth grades and students processed using the Correlation analysis. 
Table 6. Statistical data of the correlation relationship of types of anxiety.

\begin{tabular}{|c|c|c|c|c|c|c|c|}
\hline & & Sex & Age & $\begin{array}{l}\text { General } \\
\text { anxiety }\end{array}$ & $\begin{array}{l}\text { School } \\
\text { anxiety }\end{array}$ & $\begin{array}{l}\text { Self- } \\
\text { esteem } \\
\text { anxiety }\end{array}$ & $\begin{array}{l}\text { Interpersonal } \\
\text { anxiety }\end{array}$ \\
\hline \multirow[t]{3}{*}{$\operatorname{sex}$} & $\begin{array}{c}\text { Pearson } \\
\text { correlation }\end{array}$ & 1 & $0.237 * *$ & -0.07 & -.043 & -.015 & 0.137 \\
\hline & $\begin{array}{c}\text { Value } \\
\text { (2-Sided) }\end{array}$ & & 0.000 & 0.899 & 0.457 & 0.790 & 0.017 \\
\hline & $\mathrm{N}$ & 300 & 300 & 300 & & 300 & 300 \\
\hline \multirow[t]{3}{*}{ age } & $\begin{array}{c}\text { Pearson } \\
\text { correlation }\end{array}$ & $.237 * *$ & 1 & -.022 & -.043 & .000 & -.089 \\
\hline & $\begin{array}{c}\text { Value } \\
\text { (2-Sided) }\end{array}$ & .000 & & .700 & .453 & 1.000 & .125 \\
\hline & $\mathrm{N}$ & 300 & 300 & 300 & 300 & 300 & 300 \\
\hline \multirow{3}{*}{$\begin{array}{l}\text { General } \\
\text { anxiety }\end{array}$} & $\begin{array}{c}\text { Pearson } \\
\text { correlation }\end{array}$ & -.007 & -.022 & 1 & $0.506^{* *}$ & $0.630 * *$ & $0.534 * *$ \\
\hline & $\begin{array}{c}\text { Value } \\
\text { (2-Sided) }\end{array}$ & 0.899 & 0.899 & 0.700 & & 0.000 & 0.000 \\
\hline & $\mathrm{N}$ & 300 & 300 & 300 & & 300 & 300 \\
\hline \multirow{3}{*}{$\begin{array}{l}\text { School } \\
\text { anxiety }\end{array}$} & $\begin{array}{c}\text { Pearson } \\
\text { correlation }\end{array}$ & -.043 & -.043 & -.043 & $0.506^{* *}$ & 1 & $0.489 * *$ \\
\hline & $\begin{array}{c}\text { Value } \\
\text { (2-Sided) }\end{array}$ & 0.457 & 0.457 & 0.453 & 0.000 & & 0.000 \\
\hline & $\mathrm{N}$ & 300 & 300 & 300 & 300 & 300 & 300 \\
\hline \multirow{3}{*}{$\begin{array}{l}\text { Self-esteem } \\
\text { anxiety }\end{array}$} & $\begin{array}{c}\text { Pearson } \\
\text { correlation }\end{array}$ & -.015 & -.015 & 0.000 & $0.630 * *$ & $0.489 * *$ & 1 \\
\hline & $\begin{array}{c}\text { Value } \\
\text { (2-Sided) }\end{array}$ & 0.790 & 0.790 & 1.000 & 0.000 & 0.000 & \\
\hline & $\mathrm{N}$ & 300 & 300 & 300 & 300 & 300 & 300 \\
\hline \multirow{3}{*}{$\begin{array}{l}\text { Interpersonal } \\
\text { anxiety }\end{array}$} & $\begin{array}{c}\text { Pearson } \\
\text { correlation }\end{array}$ & $0.137^{*}$ & $0.137^{*}$ & -.089 & $0.534 * *$ & $0.381 * *$ & $0.510^{* *}$ \\
\hline & $\begin{array}{c}\text { Value } \\
\text { (2-Sided) }\end{array}$ & 0.017 & 0.017 & 0.000 & 0.125 & 0.000 & 0.000 \\
\hline & $\mathrm{N}$ & 300 & 300 & 300 & 300 & 300 & 300 \\
\hline
\end{tabular}

Data obtained using correlation analysis indicate an existing positive correlation between gender characteristics and interpersonal anxiety. Age is not associated with anxiety, i.e. manifestations of emotionally negative difficulties are not associated with a specific age stage. General anxiety correlates with school, self-esteem and interpersonal anxiety, which confirms the reliability of statistical processing. The existing positive correlation between school, self-esteem, and interpersonal anxiety indicates that the relationship is directly proportional. The higher the indicators of one type of anxiety, the higher the indicators of another. Interestingly, gender characteristics correlate with interpersonal anxiety. These indicators require additional analysis and research to determine the relationship and causes.

\section{Discussion}

Based on the results of the study, the sides of public life and the situations that cause the greatest concern for students and schoolchildren were identified. They should be the 
starting point for the prevention of anxiety and reduce its level in order to increase the productivity of training and subsequent work, the fulfillment of social roles that meet the requirements of society and personal beliefs.

\section{Conclusions}

This study showed that the nature of the occurrence of students' anxiety is different and is not always related with external factors, but in many respects depends on the personality of the young person. The indicators of general anxiety are quite high in all the studied groups, which indicate a tendency to neurotization of modern students, which requires preventive and corrective measures to reduce the emotional distress of modern youth.

The obtained statistics confirm that there is no correlation between anxiety and age, i.e. anxiety is not tied to any age.

A qualitative difference was found between the anxiety rates among school and university graduates compared with the other studied group of fifth graders. School anxiety goes into university anxiety and increases significantly, which may be associated with the "final stage" of students' lives, because the ninth grade and the last year of university are final and significant in the life of young people. This important point must be taken into account in educational and pedagogic moments, such stages are transitional and require careful attitude and understanding of the psychological components of this period of students' lives. A positive correlation between all types of anxiety, i.e. an increase in the indicators of one type of anxiety, gives an increase in the data of other types of anxiety, which proves the general nature of the occurrence and the relationship.

In the interpersonal anxiety scale, there is a difference in all age indicators, which was confirmed by a correlation analysis. This type of anxiety is also related to gender, but these data require more detailed study.

Factor analysis revealed and confirmed the data available in psychological science that the nature of anxiety in adolescents and young people is associated with the social sphere, interpersonal relationships, as well as personal problems and inferiority complexes. Systematic work on the prevention and correction of anxiety in students and schoolchildren will reduce the degree of neurotic society, build education and training based on knowledge of the factors that cause the greatest anxiety in certain age and gender groups.

\section{Acknowledgments}

We express special gratitude to the vice-rector for scientific work of Moscow Region State University, doctor of pedagogical sciences, doctor of historical sciences, professor E.A. Pevtsova for her great contribution to the development of scientific activity at Moscow Region State University.

\section{References}

1. A.D. Andreevna, Mental health of children and adolescents (Moscow, Academy, 2000)

2. V.N. Astapov, Journal of Psychology 13(5), 22 (1992)

3. A.I. Zakharov, Neuroses in children and adolescents: anamnesis, etiology and pathogenesis (Leningrad, Medicine, 1998)

4. V.G. Kolyagina, Psychological features of fears of preschool children with speech development deficiencies. Extended abstract of Cand. Sci. (Psychology) (Moscow, 
Moscow State University of Psychology and Education, 2011)

5. V.G. Kolyagina, Preschool education 4, 100 (2015)

6. V.M. Minaeva, The development of emotions of preschoolers. Lessons. Games (Moscow, ARKTI, 2001)

7. A.M. Prikhozhan, Anxiety in children and adolescents: Psychological nature and age dynamics (Moscow, MPSI, 2000)

8. E.G. Petrova, Journal of the Taganrog State Pedagogical Institute 2, 152 (2010)

9. A.A. Yadrova, K.P. Yadrov, Innovative methods for the prevention and correction of developmental disorders in children and adolescents: interprofessional interaction Collection of materials of the I International Interdisciplinary Scientific Conference (2019) 